\title{
Psychometric properties of the polish updated Illinois rape myth acceptance scale
}

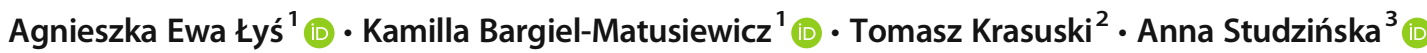

Accepted: 3 December 2020 / Published online: 6 February 2021

(C) The Author(s) 2021

\begin{abstract}
Stereotyped beliefs concerning rape, called rape myths, are a global problem. The aim of the studies was to assess the psychometric properties of the Polish version of the Updated Illinois Rape Myth Acceptance Scale which is used to assess rape myth acceptance. The tool has a high internal consistency $(\alpha=.92)$ and an overly good test-retest reliability (the It Wasn't Really Rape subscale being one exception), The five-factor model fits the data better than the four-factor one. Both in the case of the fourfactor and the five-factor models the brief version fits the data better than the full one. The study also demonstrated positive correlations of rape myth acceptance with right-wing authoritarianism, social dominance orientation, system justification, cultural conservatism, hostile sexism, benevolent sexism, beliefs in biological origins of the differences between men and women and unjust world beliefs. The correlation between rape myth acceptance and beliefs in cultural origins of the differences between men and women was negative. The analyses suggest that the Polish Updated Illinois Rape Myth Acceptance Scale is a reliable and valid tool and can be useful for further studies of rape myth acceptance.
\end{abstract}

Keywords Rape $\cdot$ Rape myths $\cdot$ Rape myth acceptance $\cdot$ Sexual violence $\cdot$ Ambivalent sexism $\cdot$ System justification theory

According to The National Intimate Partner and Sexual Violence Survey (Smith et al. 2017) conducted among 41,174 people living in the USA $19.1 \%$ of women have experienced rape at some point in their life. The definitions of rape vary between studies. According to some definitions rape is coerced penetration (e.g., the definition by WHO, see: Krug et al. 2002, p. 149), other, less conservative, do not consider penetration to be an inherent aspect of rape and put emphasis on lack of consent (Helgeson 2005).

\section{Rape Myths}

Rape myths are various false assumptions concerning rape. One of the first scientific descriptions of rape myths can be found in Martha R. Burt's work Cultural Myths and Supports

Agnieszka Ewa Łyś

agnieszka.lys@psych.uw.edu.pl

1 University of Warsaw, Warsaw, Poland

2 Medical University of Warsaw, Warsaw, Poland

3 University of Economics and Human Sciences in Warsaw, Warsaw, Poland for Rape. According to her, rape myths are "prejudicial, stereotyped or false beliefs about rape, rape victims and rapists" (Burt 1980, p. 217). One of the more common rape myths is that the typical rape perpetrator is a stranger. While the data show that an overwhelming majority of rape victims knew their perpetrator before the rape (Iconis 2008; Moyano et al. 2017; Sarmiento 2011; Waterhouse et al. 2016). According to The National Intimate Partner and Sexual Violence Survey (Smith et al. 2017) only $12.8 \%$ of rapes on women in USA are perpetrated by strangers. The myth that a husband cannot rape his wife is reflected even by legal systems in some countries - in some states of the USA the marital rape exemption existed until 1993 (McMahon 2005; see also: Herman 1984; Fus 2006) and in Nigeria it still exists (Criminal Law of Lagos State 2011, art. 260; Penal Code Act [Nigeria] 1960, art. 282). A number of rape myths consists of victim blaming and suggesting that the victim provoked the perpetrator, for example by wearing revealing clothes or by drinking alcohol (Chudasama et al. 2013; Saunders 2012).

Rape myths are a problem also in Poland- e.g. in 2014 a Polish right-wing politician (currently a parliamentarian) Janusz Korwin-Mikke in a TV show "Kropka nad i" said that women always resist a bit and thus every sexual encounter with a woman is some kind of rape (TVN24 2014). Recently, in 2020, a perpetrator of a rape on a 14-year-old girl 
obtained a suspended sentence and the justification of the judgment was that the girl had not been screaming (Gazeta Wrocławska 2020).

\section{Why Is It Important to Study Rape Myth Acceptance?}

There is some evidence that a high level of rape myth acceptance may be a predictor of sexual violence perpetration (Abbey et al. 2011; Jewkes et al. 2011; Koss and Dinero 1988; Malamuth et al. 1995). Moreover, Hudson et al. (2002) demonstrated that among sexual offenders a high level of rape myth acceptance is a risk factor for re-offending.

Rape myth acceptance among rape victims is also an important issue. There is some evidence for a negative correlation between the level of rape myth acceptance and the likelihood of reporting the rape to the police (Egan and Wilson 2012; Heath et al. 2013). Unsympathetic social reactions to sexual violence inherently related to rape myths (such as victim blaming) are also crucial to consider. Previous studies demonstrated that negative social reactions to disclosure of sexual violence were related to worse functioning of rape victims, such as them experiencing more depressive and posttraumatic stress disorder (PTSD) symptoms (Orchowski et al. 2013; Relyea and Ullman 2015; Ullman et al. 2006).

The link between social reactions to rape and PTSD may also be analyzed from the perspective of social acknowledgement. Social acknowledgement in the context of PTSD is defined as the victim's experience of positive reactions from the society that show appreciation of the victim's traumatic experience and acknowledge the difficulty of a given situation (Müller et al. 2008). Empirical studies have found that a subjective lack of social acknowledgement predicts higher levels of PTSD symptoms and may impact how trauma victims process their traumatic experiences emotionally and cognitively (Maercker and Müller 2004). Social acknowledgement may have a positive influence on the healing process (Maercker and Müller 2004; Maercker et al. 2009).

The level of rape myth acceptance among professionals who work with rape victims is also important. Hine and Murphy (2018) demonstrated a direct link between rape myth acceptance among police officers and their perception of rape victims and the credibility of their testimonies. There is also some evidence that police officers are less inclined to believe the victim when the rape was committed by her partner or husband (Areh et al. 2009; Hine and Murphy 2017). That suggests that some police officers are influenced by the myth of a" real rape" - a rape perpetrated by a stranger.

The studies mentioned before show that rape myth acceptance is a considerable problem and that it is important to study it and work out the methods which can be helpful in reducing it.
Measurement of Rape Myth Acceptance

One of the most popular scales measuring rape myths is the Illinois Rape Myth Acceptance Scale (IRMA). Studies conducted by Payne et al. (1999), confirmed its good psychometric properties. McMahon and Farmer (2011) prepared its updated version. They pointed out that some of the rape myths were no longer socially acceptable and thus the rape myths became more subtle. At first they assumed that rape myth acceptance consisted of four subfactors: She Asked For It, He Didn't Mean To, It Wasn't Really Rape and She Lied. However, after data analysis they modified their theory by adding a fifth subfactor - it turned out that the items related to alcohol intoxication of the perpetrator, previously included in the subscale He Didn't Mean To, constitute a separate, fifth subfactor.

Both versions of the Illinois Rape Myth Acceptance Scale were constructed in the USA. Nevertheless, there is some evidence that the level of rape myth acceptance varies across countries and cultures (Barn and Powers 2018; Heaven et al. 1998; Lee et al. 2005; Schneider et al. 2009; Stephens et al. 2016; Yamawaki and Tschanz 2005). Thus it is important to explore the causes and correlates of this phenomenon in various countries, not only in the USA. Sexual violence is a widespread problem in Poland. According to the study conducted on a sample of 447 Polish women, representative in terms of age, education and place of residence, $22.4 \%$ of them experienced rape at some point in their life after turning 15 years old (Grabowska and Rawłuszko 2016). Therefore the beliefs concerning rape in Poland are also worth exploring and we need a reliable and valid Polish tool for assessing rape myth acceptance.

\section{Current Studies}

The main purpose of our studies was to assess the reliability and validity of the Polish version of Updated Illinois Rape Myth Acceptance Scale, prepared by Debowska et al. (2015) who had translated the original questionnaire to Polish, then back-translated it and then consulted with three experts who suggested minor changes. Confirmatory Factor Analysis was conducted in $\mathrm{R}$ using the lavaan package (Rosseel 2019). Other analyses were conducted in SPSS. All the tools used in the studies have been approved by the Committee on Ethics of Scientific Research at the Faculty of Psychology at the University of Warsaw.

\section{Study 1. Reliability and the Factor Structure of the Polish Updated IRMA}

In Study 1 we aimed to explore the internal consistency and factor structure of the Polish Updated Illinois Rape Myth 
Acceptance Scale. We aimed to check whether the models created by McMahon and Farmer (2011) were valid also in a Polish sample. Many studies demonstrated that men had a higher level of rape myth acceptance than women (Chapleau and Oswald 2013; Chapleau and Oswald 2014; Hantzi et al. 2015; Herweyer 2015; Russell and Hand 2017; Suarez and Gadalla 2010; Vance et al. 2015; van der Bruggen and Grubb 2014). Thus we hypothesised that in our sample men will also have a higher level of rape myth acceptance than women (H1). Considering the evidence that this difference is consistent across cultures (Ward 1995, as cited in: Sakall1Uğurlu et al. 2007), we assumed that if men had a higher score on the Polish Updated Illinois Rape Myth Acceptance Scale than women, it will serve as evidence of the construct validity of the tool.

\section{Materials and Method}

\section{Measure}

Rape Myth Acceptance We used the Polish version of Updated Illinois Rape Myth Acceptance Scale (McMahon and Farmer 2011) prepared by Debowska et al. (2015). The tool consists of 19 items scored on a 5-point Likert scale. We used a scale from 1 _-" strongly disagree" to 5 _-" strongly agree" meaning that the higher the score in the questionnaire the higher the level of rape myth acceptance. ${ }^{1}$ The tool is presented in Appendix Table 7.

A study conducted in Poland (Debowska et al. 2015) among 160 students and 129 prisoners demonstrated that the tool has a high internal consistency ( $\alpha=0.87$ ). However, it would be beneficial to further explore the psychometric parameters of the tool and this was the purpose of the current study.

\section{Participants and Procedure}

The sample consisted of two subsamples: a convenience sample of Polish users of Facebook (students and graduates) who filled out an online questionnaire and a sample of Polish students recruited at the University of Warsaw, Medical University of Warsaw and Warsaw University of Technology who filled out a paper-and-pencil version of the questionnaire. We decided to conduct the analyses on the two subsamples together in order to ensure that the sample has at least 4 observations for one free parameter (Guay et al. 2014). The participation in the study was non-remunerated. The sample consisted of 834 participants, including 547 women (65.6\%) and 282 men (33.8\%). The other 5

\footnotetext{
${ }^{1}$ Some authors (including McMahon and Farmer 2011) use a reversed scale (1-" strongly agree", 5 - " strongly disagree"). We decided to use the same scale as Debowska et al. (2015), so that the results were more clear and intuitive.
}

participants $(0.6 \%)$ did not indicate their gender. The mean age for the sample was $21.64(\mathrm{SD}=4.1)$. The sample consisted of $147(18 \%)$ students of human sciences, 244 (29\%) students of social sciences, $262(31 \%)$ students of medical sciences and $181(22 \%)$ students of STEM sciences. 360 (43\%) participants took part also in a study concerning male rape myth acceptance (submitted) and sexism toward men ( Łyś et al. 2021).

\section{Results}

The mean level of rape myth acceptance was 38.46 $(S D=11.76)$. The Shapiro-Wilk test demonstrated that the distribution of rape myth acceptance differed significantly from normal $(W=.96, d f=834, p<.001)$.

\section{Four-Factor Model}

Confirmatory Factor Analysis (CFA) In order to test the fourfactor model described by McMahon and Farmer (2011) we conducted CFA. The Satorra-Bentler correction for the nonnormality of the data was applied, as well as the bootstrapping. The model is presented in Fig. 1.

As can be seen in Table 1, the CFI and TLI are below the threshold of acceptability which is .90, according to Awang (2012). The chi2/df ratio should be lower than 5 (Awang 2012), and as such it is too high.

Exploratory Structural Equation Modelling (ESEM) In order to improve the existing model, we performed an ESEM, following the recommendations of Guàrdia-Olmos et al. (2013). We then performed the EFA, setting the number of factors to four. The results are presented in Table 2 .

Based on the data presented in Table 2 we decided to ascribe the items 9 and 10 to It wasn't Really Rape scale (instead of He Didn't Mean To scale, as in model 1). We tested the obtained model using CFA. As can be observed in Table 1, the model fits the data better than the original one.

Brief Version of Updated IRMA- Four-Factor Model As shown in Table 1, the modified model fits the data better than the original one. It reaches the thresholds of acceptability suggested by Awang (2012). However the CFI and TLI were still below the level demonstrating that the model is good. According to Awang (2012) and Hu and Bentler (1999) in order for a model to be good this level needs to be .95 . Thus we concluded that it may be good to create a brief version of the tool. Bendixen and Kennair (2017), who created a Norwegian 8-item version of Updated Illinois Rape Myth Acceptance Scale, underscore that brief scales may be less prone to attrition than the longer ones. Therefore we decided to create a brief version of Polish Updated Illinois Rape Myth Acceptance Scale. It consists of eight items - the items with 
Fig. 1 The conceptual Fourfactor model of rape myth acceptance according to McMahon and Farmer (2011)

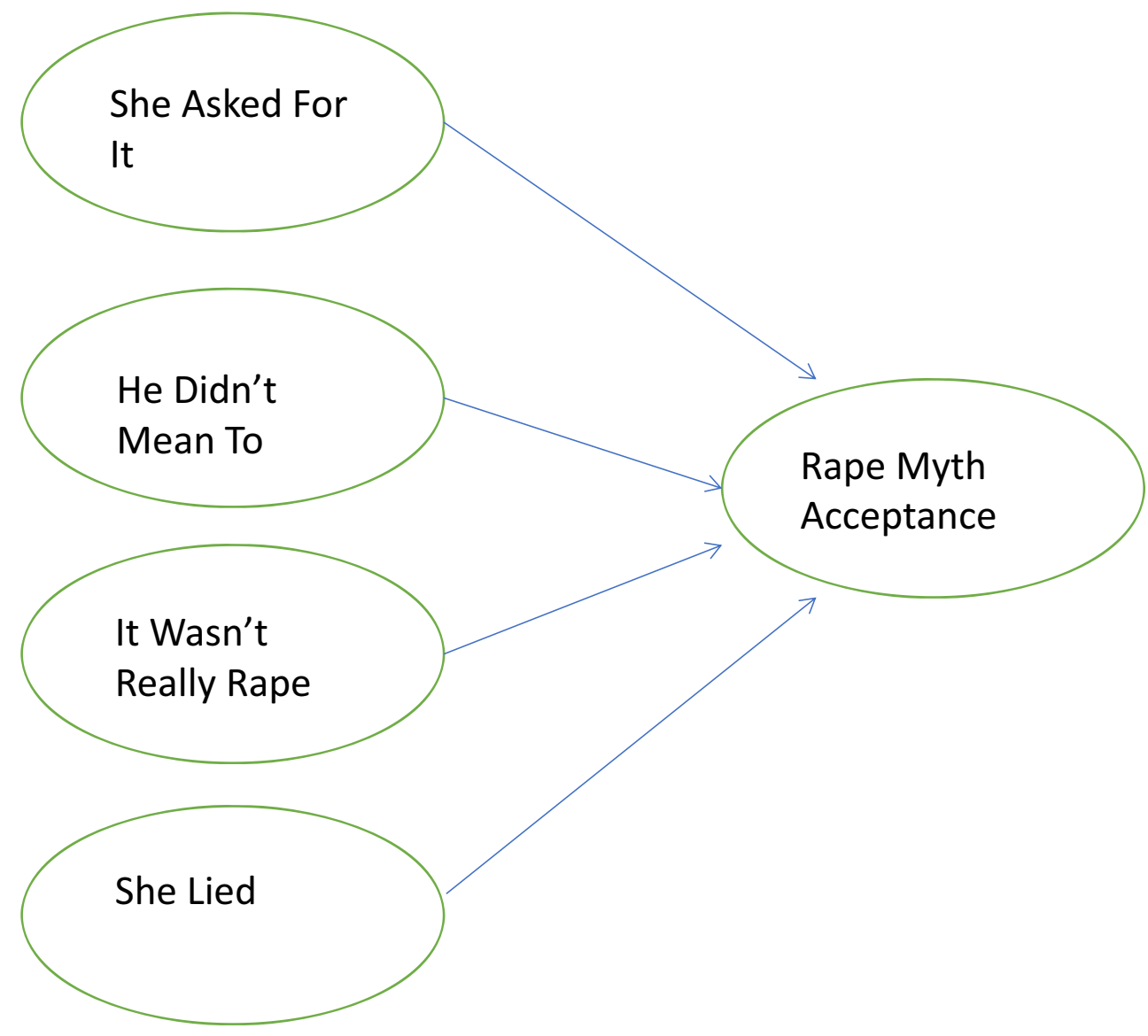

the highest factor loadings. The items 10 (It shouldn't be considered rape if a guy is drunk and didn't realize what he was doing.) and 11 (If a girl doesn't physically resist sex-even when protesting verbally-it really can't be considered rape.) had exactly the same factor loadings thus we chose the item 10 , considering that item 11 has a very similar meaning to item 12 (If a girl doesn't physically fight back, you can't really say it was rape.). The same problem occurred in the case of items 13 (A lot of times, girls who say they were raped agreed to have sex and then regret it.) and 14 (Rape accusations are often used as a way of getting back at guys.). Thus we chose the item 14 , considering that item 13 has a very similar meaning to the item 15 (A lot of times, girls who say they were raped often led the guy on and then had regrets.). The results are presented in Table 2. The items that are included in the brief version are bolded.

As presented in Table 1, the brief version fits the data better than the two longer ones.

\section{Five-Factor Model}

As we mentioned before, McMahon and Farmer (2011) previously hypothesised that the four-factor model would fit the data best, nonetheless, they modified their theory given that alcohol-related rape excusing turned out to be a separate factor. Thus we decided to test the five-factor model on the Polish sample.

Table 1 Goodness-of-fit statistics for the estimated models on the Polish Updated IRMA

\begin{tabular}{|c|c|c|c|c|c|c|c|c|}
\hline model & Chi2 & df & & CFI & TLI & RMSEA & RMSEA CI & SRMR \\
\hline Model 1 (4-factors, CFA) & $844.34 * *$ & 146 & 5.78 & .89 & .88 & .07 & $.07-.08$ & .06 \\
\hline Model 2 (4-factors, ESEM) & $592.35 * *$ & 146 & 4.05 & .94 & .92 & .06 & $.05-.06$ & .06 \\
\hline (Model 3 4-factors, brief version, CFA) & $23.140 * *$ & 14 & 1.65 & .99 & .99 & .02 & $.00-.04$ & .02 \\
\hline Model 4 (5-factors, CFA) & $478.40 * *$ & 142 & 3,36 & .95 & .94 & .05 & $.04-.06$ & .05 \\
\hline (Model 5 5-factors, brief version, CFA) & $76.79 * *$ & 25 & 3,07 & .98 & .97 & .04 & $.03-.05$ & .03 \\
\hline
\end{tabular}

$* * p<.01$ 
Table 2 Exploratory factor analysis- four-factor version

\begin{tabular}{|c|c|c|c|c|c|}
\hline & Item & $\mathrm{SA}^{*}$ & MT** & $\mathrm{NR}^{* * *}$ & $\mathrm{SL} * * * *$ \\
\hline 1 & If a girl is raped while she is drunk, she is at least somewhat responsible for letting things get out of hand. & -.76 & & & \\
\hline 2 & When girls go to parties wearing slutty clothes, they are asking for trouble. & -.78 & & & \\
\hline 3 & If a girl goes to a room alone with a guy at a party, it is her own fault if she is raped. & -.74 & & & \\
\hline 4 & If a girl acts like a slut, eventually she is going to get into trouble. & -.68 & & & \\
\hline 5 & When guys rape, it is usually because of their strong desire for sex. & & .75 & & \\
\hline 6 & Guys don't usually intend to force sex on a girl, but sometimes they get too sexually carried away & & 60 & & \\
\hline 7 & Rape happens when a guy's sex drive goes out of control. & & 64 & & \\
\hline 8 & If a guy is drunk, he might rape someone unintentionally. & & .38 & & \\
\hline 9 & If both people are drunk, it can't be rape. & & & -.52 & \\
\hline 10 & It shouldn't be considered rape if a guy is drunk and didn't realize what he was doing. & & & -.65 & \\
\hline 11 & If a girl doesn't physically resist sex- even when protesting verbally- it really can't be considered rape. & & & -.66 & \\
\hline 12 & If a girl doesn't physically fight back, you can’t really say it was rape. & & & -.79 & \\
\hline 13 & A lot of times, girls who say they were raped agreed to have sex and then regret it. & & & & .79 \\
\hline 14 & Rape accusations are often used as a way of getting back at guys. & & & & .79 \\
\hline 15 & A lot of times, girls who say they were raped often led the guy on and then had regrets. & & & & .85 \\
\hline 16 & A lot of times, girls who claim they were raped have emotional problems. & & & & .76 \\
\hline 17 & If the accused "rapist" doesn't have a weapon, you really can't call it rape. & & & -.60 & \\
\hline 18 & Girls who are caught cheating on their boyfriends sometimes claim it was rape. & & & & .74 \\
\hline 19 & If a girl doesn't say „no” she can’t claim rape. & & & -.47 & \\
\hline
\end{tabular}

*SA She Asked For It, **MT He Didn’t Mean To, ***NR It Wasn't Really Rape, ****SL She Lied

Confirmatory Factor Analysis (CFA) In order to test the model created by McMahon and Farmer (2011) we performed CFA. The model is presented in Fig. 2.

As shown in Table 1, CFI permits us to consider the fivefactor model as a good one, whereas TLI still is slightly below the .95 threshold (Awang 2012; Hu and Bentler 1999). As presented in Table 3, the EFA demonstrated no possibility of any changes in the model.

\section{Brief version of Updated Illinois Rape Myth Acceptance Scale} - five-factor model In order to find out whether the TLI will increase after selecting 8 items with the highest factor loading we decided also to test the properties of the brief version of the five-factor model. We chose the items according to the same criteria as in the four-factor model. The results are in Table 3. The items that are included in the brief version are marked in bold.

\section{Psychometric Properties of the Different Versions of the Scale}

The goodness of fit parameters of the abovementioned versions of the scale are presented in Table 1. The five-factor model has better goodness-of-fit indices than the four-factor one. In the case of both models the brief version fits the data better than the full one. Nevertheless, the reliability and validity of the Polish Updated Illinois Rape Myth Acceptance Scale need further research, which we undertook in Studies 2 and 3.
The internal consistency of the total scale, as well of the subscales in the different models of the full versions are presented in Table 4.

According to Awang (2012) and Arafat et al. (2016) the scale is reliable when its Cronbach's alpha is at least .70. As presented in Table 4, the total scale and all subscales, apart from the He Was Just Drunk subscale, reached this threshold.

\section{Rape Myth Acceptance, Gender and Age}

The mean level of rape myth acceptance among men and women was $40.09(S D=12.45)$ and $32.75(S D=9.88)$ respectively. The U Mann-Whitney test $(z=-9.21, p<.001)$ demonstrated that the difference between men and women was significant. Additionally we explored the link between rape myth acceptance and age and we found a significant, negative correlation $(r h o=-.28, p<.001)$.

\section{Discussion}

According to the cutoff criteria established by $\mathrm{Hu}$ and Bentler (1999), the five-factor version fits the data better than the four-factor one. Both in the case of fourfactor and five-factor models the brief version fits the data better than the longer one. Since the alcohol-related rape excusing turned out to be a separate factor, which is consistent with the data concerning the original 
Fig. 2 Five-factor model of rape myth acceptance according to McMahon and Farmer (2011)

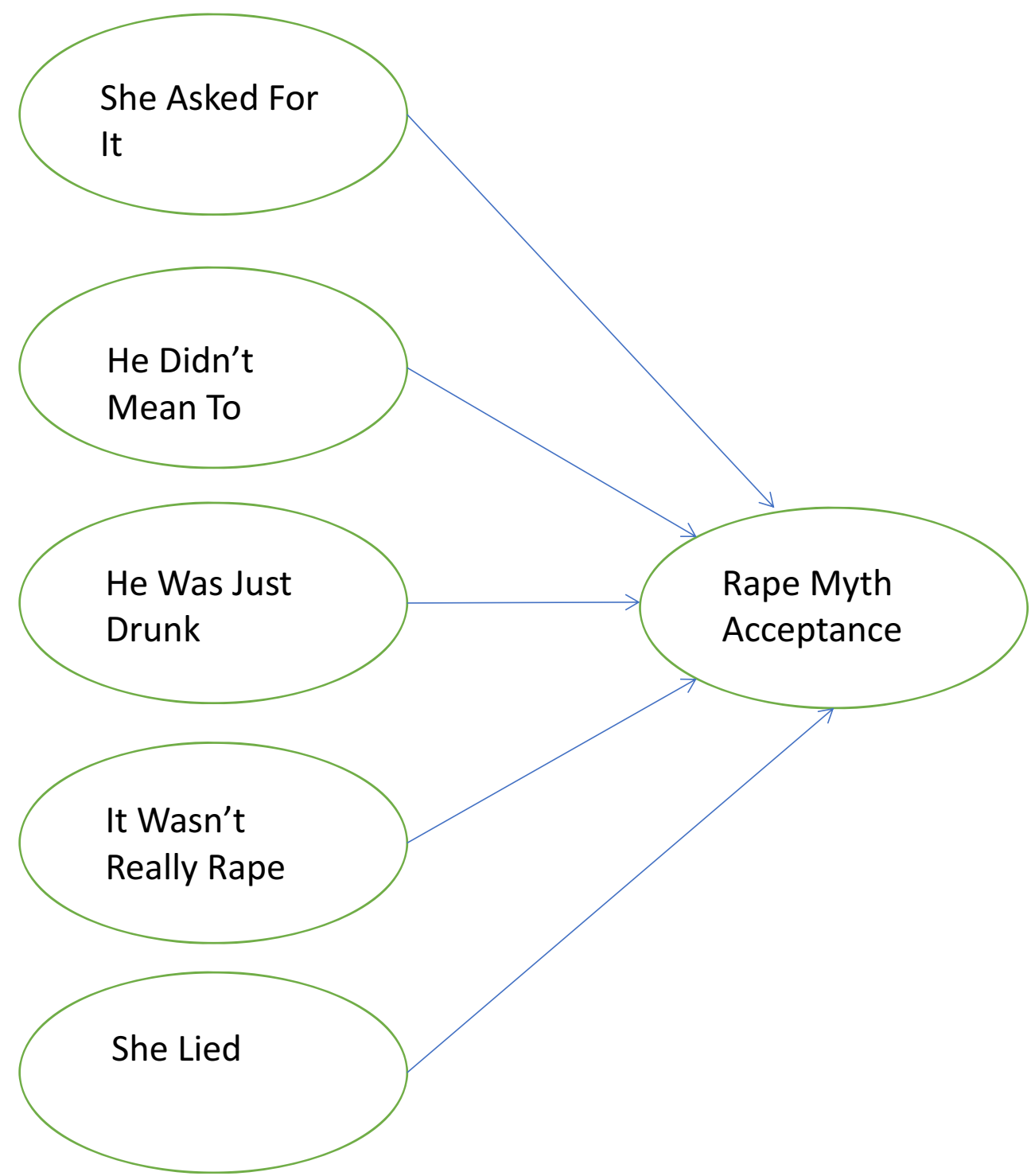

version, we decided to include the models 4 and 5 in the Study 2 and 3. According to Arafat et al. (2016) test-retest reliability is one of the most widely used measures of reliability thus we decided to check this measure in Study 2.

\section{Study 2. Test-Retest Reliability of the Polish Updated Illinois Rape Myth Acceptance Scale}

\section{Materials and Method}

\section{Measure}

Rape Myth Acceptance Polish Updated Illinois Rape Myth Acceptance Scale, used already in the Study 1.

\section{Participants and Procedure}

The questionnaire was administered a second time to 142 participants of Study 1, two weeks after the first measurement. The participants filled out the paper-andpencil version. The participation in the study was nonremunerated.

The sample consisted of $107(75 \%)$ women and 35 $(25 \%)$ men. The mean age for the sample was 21.37 $(\mathrm{SD}=2.60)$. The sample consisted of $60(42 \%)$ students of human sciences, 25 (18\%) students of social sciences, $18(13 \%)$ students of medical sciences and 39 (27\%) students of STEM sciences. 118 (83\%) participants took part also in a study concerning male rape myth acceptance (Łyś et al., submitted) and sexism toward men (Łyś et al. 2021). 
Table 3 Exploratory factor analysis- five-factor version

\begin{tabular}{|c|c|c|c|c|c|c|}
\hline & Item & $\mathrm{SL} * * * * *$ & $\mathrm{NR} * * * *$ & $\mathrm{MT}^{* *}$ & $\mathrm{SA}^{*}$ & $\mathrm{JD} * * *$ \\
\hline 1 & $\begin{array}{l}\text { If a girl is raped while she is drunk, she is at least somewhat responsible for letting things get out of } \\
\text { hand. }\end{array}$ & & & & -.76 & \\
\hline 2 & When girls go to parties wearing slutty clothes, they are asking for trouble. & & & & -.79 & \\
\hline 3 & If a girl goes to a room alone with a guy at a party, it is her own fault if she is raped. & & & & -.75 & \\
\hline 4 & If a girl acts like a slut, eventually she is going to get into trouble. & & & & -.69 & \\
\hline 5 & When guys rape, it is usually because of their strong desire for sex. & & & .78 & & \\
\hline 6 & Guys don't usually intend to force sex on a girl, but sometimes they get too sexually carried away & & & .59 & & \\
\hline 7 & Rape happens when a guy's sex drive goes out of control. & & & .64 & & \\
\hline 8 & If a guy is drunk, he might rape someone unintentionally. & & & & & .54 \\
\hline 9 & If both people are drunk, it can't be rape. & & & & & .55 \\
\hline 10 & It shouldn't be considered rape if a guy is drunk and didn't realize what he was doing. & & & & & .68 \\
\hline 11 & If a girl doesn't physically resist sex- even when protesting verbally- it really can't be considered rape. & & -.70 & & & \\
\hline 12 & If a girl doesn't physically fight back, you can't really say it was rape. & & -.83 & & & \\
\hline 13 & A lot of times, girls who say they were raped agreed to have sex and then regret it. & .79 & & & & \\
\hline 14 & Rape accusations are often used as a way of getting back at guys. & .79 & & & & \\
\hline 15 & A lot of times, girls who say they were raped often led the guy on and then had regrets. & .84 & & & & \\
\hline 16 & A lot of times, girls who claim they were raped have emotional problems. & .77 & & & & \\
\hline 17 & If the accused "rapist" doesn't have a weapon, you really can't call it rape. & & -.58 & & & \\
\hline 18 & Girls who are caught cheating on their boyfriends sometimes claim it was rape. & .74 & & & & \\
\hline 19 & If a girl doesn't say ,no” she can’t claim rape. & & -.47 & & & \\
\hline
\end{tabular}

*SA She Asked For It, **MT He Didn’t Mean To, ***JD He Was Just Drunk, ***NR It Wasn’t Really Rape, *****SL She Lied

\section{Results and Discussion}

The mean level of rape myth acceptance was $39.55(S D=$ $12.48)$ and $38.65(S D=12.59)$ during the first and the second measurement, respectively. The results of the Shapiro-Wilk test demonstrated that the distribution of rape myth acceptance differed significantly from normal both during the first measurement $(\mathrm{W}=.96, \mathrm{df}=142, p<.001)$ and the second one $(\mathrm{W}=.95, \mathrm{df}=142, p<.001)$.

In order to assess the test-retest reliability, we analyzed the correlation between the two measurements. Based on the results of Study 1 and Study 2 we decided to analyse models 4 and 5 . Due to the non-normality of the distribution of rape myth acceptance scores we decided to use the non-parametric correlation (Spearman's rho). The results are presented in Table 5. All correlations were significant at $p<.01$ level. According to Nunnally and Bernstein (1994, as cited in: Vilagut 2014) the level .70 of the testretest reliability is the threshold of acceptability. As we can see, the total score, as well as all the subscales, except for It Wasn't Really Rape and the short version of He Was Just Drunk reached this threshold.
Table 4 Internal consistency for the estimated models on the Polish Updated IRMA (Cronbach's alpha)

\begin{tabular}{lllllll}
\hline Model & $\begin{array}{l}\text { Total } \\
\text { scale }\end{array}$ & SA* & MT** & MT(JD)** & NR**** & SL***** \\
\hline Model 1 (4-factors, CFA) & .92 & .81 & .72 & NA & .72 & .89 \\
Model 2 (4-factors, ESEM) & .92 & .81 & .72 & NA & .77 & .89 \\
Model 3 (4-factors, CFA, brief version) & .81 & $.77^{\text {a }}$ & .73 & NA & .50 & .75 \\
Model 4 (5-factors, CFA) & .92 & .81 & .74 & .63 & .72 & .89 \\
Model 5 (5-factors, CFA, brief version) & .84 & .77 & .73 & .62 & .50 & .75 \\
\hline
\end{tabular}

a In the case of two-item subscales (model 3 and 5) instead of Cronbach's alpha the Spearman's-Brown formula was used (Iacobucci 2001)

*SA She Asked For It, **MTHe Didn't Mean To, ***MT(JD) He Was Just Drunk, ***NR It Wasn't Really Rape, ****SL She Lied 
Table 5 Test-retest reliability (Spearman's rho)

\begin{tabular}{lllllll}
\hline Version & Total scale & $\mathrm{SA}^{*}$ & $\mathrm{MT}^{* *}$ & $\mathrm{MT}(\mathrm{JD}) * *$ & $\mathrm{NR} * * * *$ & $\mathrm{SL} * * * * *$ \\
\hline full & .88 & .84 & .73 & .72 & .67 & .81 \\
brief & .86 & .79 & .70 & .49 & .62 & .79 \\
\hline
\end{tabular}

*SA She Asked For It, **MT He Didn’t Mean To, ***MT(JD) He Was Just Drunk, ***NR It Wasn't Really Rape, ****SL She Lied

\section{Study 3. Rape Myth Acceptance and the Social Attitudes - Construct Validity of the Polish Updated Illinois Rape Myth Acceptance Scale}

In order to further explore the construct validity of the Polish Updated Illinois Rape Myth Acceptance Scale, we decided to analyse its correlates. One of the possible explanations of rape myths is the system justfication theory according to which the stereotypes and prejudices are used to justify the existing social order and rationalize the discrimination and social inequalities (Jost and Banaji 1994). There is some evidence for positive correlation between rape myth acceptance and system justification (Chapleau and Oswald 2014; Papp and Erchull 2017). A number of studies suggests that rape myth acceptance is also related to just world belief (Russell and Hand 2017; Sakallı-Uğurlu et al. 2007; Strömwall et al. 2013; Vonderhaar and Carmody 2014) which is not identical with system justification but is inherently related to it. Both attitudes are based on the assumption that people generally deserve their fate. Other important predictors of rape myth acceptance are: exposure to violence in childhood (Debowska et al. 2015; Debowska et al. 2016), psychopathy (Debowska et al. 2015), social dominance orientation (Hantzi et al. 2015), right-wing authoritarianism (Giovannelli and Jackson 2013; Hantzi et al. 2015), conservatism (Barnett and Hilz 2017) and sexism (Aosved and Long 2006; Chapleau et al. 2007; Cooper Stoll et al. 2017; Page 2008; Rebeiz and Harb 2010; Sakall1-Uğurlu et al. 2007). The correlation of the Polish version of Updated Illinois Rape Myth Acceptance Scale with psychopathy and with exposure to violence has been already shown by Debowska et al. (2015) thus we put the emphasis on the attitudinal correlates of rape myth acceptance in our studies.

So far there is no direct evidence for the link between the rape myth acceptance and the beliefs concerning the origin of differences between men and women. Nevertheless, some studies demonstrate a link between gender essentialism and various gender-related stereotypes and prejudices, for example ambivalent sexism towards women (Studzińska and Wojciszke 2014), lack of support for women's rights (Skewes et al. 2018; Studzińska and Wojciszke 2014; Wilton et al. 2018), negative attitudes toward counterstereotypical candidates in election (Swigger and Meyer 2018), transphobia (Broussard and Warner 2018; Ching and
$\mathrm{Xu}$ 2018; Wilton et al. 2018) and perceiving same-gender parenting as unnatural and harmful for children (Pacilli et al. 2017). Thus we included also the beliefs concerning the origins of differences between men and women in our analysis.

\section{Hypotheses}

H1. The score on the Polish Updated Illinois Rape Myth Acceptance Scale will be positively correlated with the following variables:

a. System justification;

b. Social dominance orientation;

c. Right-wing authoritarianism;

d. Cultural conservatism;

e. Hostile sexism;

f. Benevolent sexism;

g. Beliefs in biological origins of the differences between men and women

H2. The score on the Polish Updated Illinois Rape Myth Acceptance Scale will negatively correlate with the following variables:

A. Beliefs in cultural origins of differences between men and women

B. Unjust world beliefs

Should the majority of the hypotheses be confirmed, then the tool meets the criteria of construct validity.

\section{Materials and Method}

\section{Measures}

Rape Myth Acceptance Polish Updated Illinois Rape Myth Acceptance Scale, as described in Studies 1 and 2.

System Justification System Justification Scale (Kay and Jost 2003) measures the tendency to support the existing social order (e.g., Society is set up so that people usually get what they deserve.). The tool has been adapted to Polish by Klebaniuk (2010). It consists of 8 items scored on a 5-point Likert scale. Its internal consistency in our sample was $\alpha=.72$.

Social Dominance Orientation Social Dominance Scale (Sidanius and Pratto 1999, as cited in: Klebaniuk 2010) measures the tendency to legitimize inequalities in the society (e.g., It's probably a good thing that certain groups are at the top and other groups are at the bottom.). The tool has been adapted to Polish by Klebaniuk (2010). It consists of 16 items scored on a 5 -point Likert scale. Its internal consistency in our sample is $\alpha=.87$. 
Right-Wing Authoritarianism Right-Wing Authoritarianism scale (Funke 2005) measures the model of Right-Wing Authoritarianism including three factors: submission (e.g., The real keys to the "good life" are obedience, discipline, and virtue.), aggression (e.g., What our country really needs instead of more "civil rights" is a good stiff dose of law and order.) and conventionalism (e.g.,The withdrawal from tradition will turn out to be a fatal fault one day.). The tool has been adapted to Polish by Grzesiak-Feldman (2012). It consists of 12 items scored on a 5-point Likert scale. Its internal consistency in our sample is $\alpha=.77$.

Conservatism Political Opinion Questionnaire by Wojciszke (Radkiewicz 2011) measures the endorsement of right-wing ideology. The tool consists of 20 items scored on a 5-point Likert scale. It has two subscales: social conservatism (e.g., The Christian values should be specially protected in Poland.) and economic conservatism (e.g., Currently the richest people pay too high taxes.). We included the social subscale in our analysis. Its internal consistency in our sample was $\alpha=.89$.

Hostile and Benevolent Sexism Ambivalent Sexism Inventory (Glick and Fiske 1996) measures two dimensions of ambivalent sexism: hostile sexism, based on explicitly hostile beliefs about women (e.g., Women seek to gain power by getting control over $m e n$.) and benevolent sexism, based on apparently supportive attitudes toward women (e.g., A good woman should be set on a pedestal by her man.). The tool has been adapted to Polish by Mikołajczak and Pietrzak (2014). The Polish version consists of 22 items scored on a 6-point Likert scale. Its internal consistency in our sample was $\alpha=.93$ for the hostile sexism subscale and $\alpha=.90$ for the benevolent sexism subscale.

Beliefs Concerning the Origins of Gender Differences Beliefs in Origins of Gender Differences Questionnaire (Studzińska and Wojciszke 2014) measures the beliefs in biological (e.g., All the differences between men and women are created by nature.) and in cultural (e.g., Men and women differ because they are raised in different way.) origins of differences between men and women. The tool consists of 13 items scored on a 7-point Likert scale. Its internal consistency in our sample was $\alpha=.84$ for the Beliefs in Biological Origins of Gender Differences subscale and $\alpha=.87$ for the Beliefs in Cultural Origins of Gender Differences subscale.

Unjust World Beliefs Scale "What is the world?" (Skrzypińska 2003) measures the perception of the world as a place where unfair things happen often (e.g., In many cases innocent people suffer unnecessarily.). The tool consists of 10 items scored on a 7-point Likert scale. It was constructed in order to assess the just world beliefs but only the negative items turned out to be valid, therefore the scale measures the unjust world beliefs. Its internal consistency in our sample was $\alpha=.72$.
Social Desirability Bias Social Desirability Questionnaire (Drwal and Wilczyńska 1980) measures the tendency for positive self-presentation (e.g., I never resent being asked to return a favor). The tool is based on Marlowe-Crowne Social Desirability Scale (Crowne and Marlowe 1960). It consists of 29 items scored on a nominal scale (yes/no). Its internal consistency in our sample is $\alpha=.74$.

\section{Participants and Procedure}

The sample consisted of 433 Polish students recruited at the University of Warsaw, Medical University of Warsaw and Warsaw University of Technology, including 120 men $(27.7 \%)$ and 309 women (71.4\%), 3 participants who did not indicate their gender and one who described themselves as non-binary. The mean age was $21.20(\mathrm{SD}=3.33)$. The sample consisted of $110(26 \%)$ students of human sciences, $177(41 \%)$ students of social sciences, $86(19 \%)$ students of medical sciences, 42 (10\%) students of STEM sciences and 18 (4\%) of students who did not report their field of study. The participants filled out a paper-and-pencil version of the questionnaire. The participation in the study was non-remunerated. $210(49 \%)$ participants took part also in a study concerning male rape myth acceptance (Łyś et al., submitted) and sexism toward men (Łyś et al. 2021).

\section{Results}

The mean level of rape myth acceptance in the sample was $34.86(S D=11.21)$. The results of the Shapiro-Wilk test $(\mathrm{W}=.95, \mathrm{df}=433, p=.001)$ indicated that the distribution of rape myth acceptance in the sample differed significantly from normal distribution.

\section{Correlations of Rape Myth Acceptance with Attitudinal Variables}

As the distribution was not normal, we chose to use Spearman's rho coefficient. The positive correlations between rape myth acceptance and social dominance orientation, right-wing authoritarianism, system justification, both forms of sexism and beliefs in biological origins of differences between men and women were statistically significant. Unexpectedly, the correlation between rape myth acceptance and just world belief turned out to be positive as well. The results are presented in Table 6 .

\section{General Discussion}

Factor analysis, conducted in Study 1, demonstrated that the fivefactor model fits the data better than the four-factor one. This is consistent with the findings of McMahon and Farmer (2011) who modified their theory when it turned out that alcohol-related rape 
Table 6 Correlates of RMA (Spearman's $\rho$ )

\begin{tabular}{|c|c|c|c|c|c|c|c|c|c|c|c|}
\hline & Version & SJ & SDO & RWA & $\mathrm{CC}$ & HS & $\mathrm{BS}$ & $\mathrm{BO}$ & $\mathrm{CO}$ & UWB & $\mathrm{SD}$ \\
\hline \multirow[t]{2}{*}{ Total scale } & Full & $.28 * *$ & $.42 * *$ & $.54 * *$ & $.42 * *$ & $.68 * *$ & $.50 * *$ & $.45^{* *}$ & $-.18 * *$ & $.17 * *$ & .07 \\
\hline & Brief & $.26^{* *}$ & $.39 * *$ & $.51 * *$ & $.39 * *$ & $.63 * *$ & $.49 * *$ & $.42 * *$ & $-.17 * *$ & $.18^{* *}$ & .06 \\
\hline \multirow[t]{2}{*}{ SA } & Full & $.27 * *$ & $.42 * *$ & $.57 * *$ & $.46^{* *}$ & $.62 * *$ & $.48^{* *}$ & $.43 * *$ & $-.22 * *$ & $.14 * *$ & .03 \\
\hline & Brief & $.26 * *$ & $.34 * *$ & $.55^{* *}$ & $.44 * *$ & $.50 * *$ & $.42 * *$ & $.39 * *$ & $-.17 * *$ & .06 & .00 \\
\hline \multirow[t]{2}{*}{ MT } & Full & $.12 *$ & $.24 * *$ & $.24 * *$ & $.23 * *$ & $.38 * *$ & $.34 * *$ & $.31 * *$ & -.07 & $.21 * *$ & .05 \\
\hline & Brief & .08 & $.24 * *$ & $.23 * *$ & $.21 * *$ & $.34 * *$ & $.32 * *$ & $.29 * *$ & -.07 & $.24 * *$ & -.01 \\
\hline \multirow[t]{2}{*}{ JD } & Full & $.18^{* *}$ & $.23 * *$ & $.35^{* *}$ & $.24 * *$ & $.40 * *$ & $.29 * *$ & $.26^{* *}$ & -.05 & .05 & $.11 *$ \\
\hline & Brief & $.16^{* *}$ & $.15^{* *}$ & $.31 * *$ & $.27 * *$ & $.36 * *$ & $.32 * *$ & $.25^{* *}$ & -.04 & .02 & .03 \\
\hline \multirow[t]{2}{*}{ NR } & Full & $.19 * *$ & $.21^{* *}$ & $.34 * *$ & $.27 * *$ & $.39 * *$ & $.33 * *$ & $.29 * *$ & $-.11 *$ & .02 & .06 \\
\hline & Brief & $.17 * *$ & $.24 * *$ & $.22 * *$ & $.19 * *$ & $.34 * *$ & $.25^{* *}$ & $.17 * *$ & $-.14 *$ & .00 & $.12 *$ \\
\hline \multirow[t]{2}{*}{ SL } & Full & $.24 * *$ & $.40 * *$ & $.47^{* *}$ & $.34 * *$ & $.65^{* *}$ & $.43^{* *}$ & $.39 * *$ & $-.18^{* *}$ & $.17^{* *}$ & .02 \\
\hline & Brief & $.22 * *$ & $.35^{* *}$ & $.43^{* *}$ & $.28 * *$ & $.61 * *$ & $.38 * *$ & $.36^{* *}$ & $-.16^{* *}$ & $.18^{* *}$ & .03 \\
\hline
\end{tabular}

SA She Asked For It, MT He Didn’t Mean To, JD He Was Just Drunk, NR It Wasn’t Really Rape, SL She Lied, SJ System Justification, SDO Social Dominance Orientation, RWA Right-Wing Authoritarianism, CC Cultural Conservatism, EC Economic Conservatism, $H S$ Hostile Sexism, BS Benevolent Sexism, $B O$ Biological Origins of Differences Between Men and Women, $C O$ Cultural Origins of Differences Between Men and Women, $U W B$ Unjust World Belief, $S D$ Social Desirability

$* p=<.05, * * p<.01$

excusing is a separate factor, differing from more general excusing of rape.. Both in the case of the five-factor and the four-factor models the brief version of the questionnaire fits the data better than the full one. As for the reliability measures, the shorter version of It Wasn't Really Rape subscale and both versions of the He Was Just Drunk subscale have a relatively low internal consistency. Both versions of It Wasn't Really Rape subscale and the shorter version of the He Was Just Drunk have a relatively low test-retest reliability. Except for these two subscales, the results suggest that the tool has good psychometric properties: the total score, as well as the subscales She Asked For It, He Didn't Mean To and She Lied, had good internal consistency and test-retest reliability.

It is worth considering what are the causes of the relatively low test-retest reliability of the It Wasn't Really Rape and the brief version of He Was Just Drunk subscale. This results suggest that many people have a very inexact and unstable idea of what rape is. They indicate also that the results on these scales may be prone to temporal fluctuations. The mood may play a role here - according to Goldenberg and Forgas (2012), negative mood increases the tendency towards blaming the victims of the offenses, whereas positive mood reduces it.

We should also take into account the low but significant correlation of the Social Desirability Scale with the shorter version of It Wasn't Really Rape subscale and the full version of the He Was Just Drunk subscale. It is especially puzzling that this correlation is positive. This result suggests that some myths concerning the" real" and" unreal" rape, as well as the myths treating being alcohol-intoxicated as an attenuating circumstance for the perpetrator, may be socially approved or at least perceived to be so. Less direct questions, based on vignette methodology, may be useful here. Page (2010) demonstrated a difference in the police officers' attitudes toward rape depending on the wording of the question: 93\% of the participants of her study agreed with the opinion that any woman can be raped, whereas $19 \%$ of them were unlikely to believe a married woman who claimed that her husband raped her, and $44 \%$ of them were unlikely to believe a prostitute who claimed she or he was raped. It is also worth considering other tools, which are based on reactions, and not on declarations, for example Implicit Association Test (Chapleau and Oswald 2010; Süssenbach et al. 2017; Widman and Olson 2013).

Most of the hypotheses were supported. Hypothesis 1 in the Study 1 was fully supported: men had significantly higher scores in the Polish Updated Illinois Rape Myth Acceptance Scale than women. In Study 3, the Hypothesis 1 was fully supported. Positive correlations of rape myth acceptance with system justification, social dominance orientation, right-wing authoritarianism, cultural conservatism, sexism (both hostile and benevolent) and beliefs in biological origins of the differences between men and women also support the construct validity of the tool. However, in order to draw any conclusions on the cause-and-effect relationships between rape myth acceptance and the aforementioned variables, we need further studies, especially experimental ones.

The hypothesis 2 in Study 3 was partially supported. Pursuant to the Hypothesis 2a, rape myth acceptance and beliefs in cultural origins of the differences between men and women turned out to correlate negatively which also lets us to claim that the Polish version of Updated Illinois Rape Myth Acceptance Scale has a good level of construct validity. However, Hypothesis $2 \mathrm{~b}$ was not supported: the correlation between rape myth acceptance and unjust world belief turned out to be positive which is contrary to previous research results. It is difficult to determine the cause of this surprising result. Lench and Chang (2007) note that the unjust 
world belief and just world belief are two separate constructs. Moreover, in a study conducted among prisoners and guards by Dalbert et al. (2001) the unjust world belief and just world belief scales turned out to be negatively correlated only among guards. Among prisoners there was no correlation between these two variables. Thus a study of the construct validity of the scale "What is the world?" is needed. Moreover, Dalbert et al. (2001) notice that unjust world belief may promote cynical attitudes. That may result in lower sensitivity to other people's harm, including their experiences of sexual violence. It is also good to take into account that this scale was created in 1998 (Skrzypińska 2008). The concept of justice and injustice could have changed after 20 years, because of technological progress and changes in political and economical situation. Thus the correlates of the belief in just and in the unjust world could also change. Nevertheless, this hypothesis needs further verification.

Most of the variables included in Study 3, like cultural conservatism, social dominance orientation, right-wing authoritarianism, system justification, both forms of sexism and belief in biological origins of differences between men and women correlated positively with all the 5 subfactors of rape myth acceptance, but other correlated only with some of them. Unjust world belief correlated positively with She Lied, She Asked For It and He Didn't Mean To subscale, but did not correlate with the other two. Belief in cultural origins of differences between men and women correlated negatively with She Lied and She Asked For It subscales but did not correlate with the other three. These nuances need a further exploration in future studies.

\section{Limitations}

It is necessary to take into account that the research results can be influenced by the selection of the studied groups. We demonstrated a negative correlation between age and rape myth acceptance, nevertheless, we should interpret this result very cautiously, because the sample consisted predominantly of students. Moreover, Burt (1980) has demonstrated a positive correlation between rape myth acceptance and age. We may then suppose that the relationship between rape myth acceptance and age has changed since the 80 's. We cannot exclude the possibility that this relationship may be U-shaped. Recruitment to the studies was conducted among students from various faculties, including those where some topics related to rape can be discussed, like psychology, pedagogy or law. Internet use, especially after the \#metoo movement, can also be a contributory factor here. Considering that Burt (1980) demonstrated a negative correlation between educational attainment and rape myth acceptance, thus a study on a sample with more diverse age, level of education and social capital is needed. A study among sexual offenders and a control group of non-offenders would be also useful - it would shed some light on the criterion-related validity.
Another important limitation is that although both the first (Payne et al. 1999) and the updated version (McMahon and Farmer 2011) of the Illinois Rape Myth Acceptance Scale explore thoroughly the female rape myths, they do not take into account the myths concerning the rape where the victim is a man. Almost one third of 1220 adult inhabitants of the USA who participated in the survey conducted by Walfield (2018) admitted that they would have a hard time believing a man who told them that he was raped by a woman. The myth that a man cannot be raped is reflected even by legal systems in some countries, like the UK (Penal Code [UK] 2008, art. 117) and Switzerland (Swiss Criminal Code 1937/2018, art. 190). Nevertheless, according to The National Intimate Partner and Sexual Violence Survey (Smith et al. 2017) $1.5 \%$ of men in USA have experienced rape at some point in their life. According to a Polish study conducted by Izdebski (2012) $1 \%$ of men at the ages of 18 to 49 have been forced to have sexual intercourse. Thus a Polish version of a questionnaire concerning male rape myth acceptance (e.g., Melanson 1998; Struckman-Johnson and Struckman-Johnson 1992) is also needed.

\section{Conclusion}

The results of our studies suggest that the Polish Updated Illinois Rape Myth Acceptance Scale is a valid and reliable tool which can be useful for assessing the explicit beliefs on sexual violence. The brief version may be useful especially in longitudinal studies where attrition is a frequent problem and in surveys where the briefness is important. Polish Updated Illinois Rape Myth Acceptance Scale can be used both for scientific purpose and in evaluation of sexual violence prevention programs.

Data Availability Statement The data analysed in this manuscript are available in OSF: https://osf.io/eu4qd/

\section{Compliance with Ethical Standards}

Conflict of Interest On behalf of all authors, the corresponding author states that there is no conflict of interest.

Ethical Statement The project is a part of the project „Explicit and implicit attitudes towards sexual violence among law students, medicine, psychology and police school students: the most important correlates and susceptibility to change." which has been approved by the Ethical Review Board at the first author's faculty.

Informed Consent I invite you to participate in a study which is a part of my $\mathrm{PhD}$ project. It concerns opinions of sexual violence. The study is about 15 min long and consists of filling in several questionnaires. The study is completely anonymous and you can withdraw from it at any moment without giving any reason. 


\section{Appendix}

Table 7 Items of Polish Updated IRMA

\begin{tabular}{|c|c|c|c|c|}
\hline & & Model 1 & Model 2 & Model 4 \\
\hline 1 & $\begin{array}{l}\text { Jeśli dziewczyna zostanie zgwałcona kiedy jest pijana, } \\
\text { to jest ona przynajmniej troche odpowiedzialna za to, co sie stało. }\end{array}$ & $\mathrm{SA}^{*}$ & SA & SA \\
\hline 2 & Kiedy dziewczyny idą na przyjęcia ubrane w wyzywające ubrania, same proszą się o problemy. & SA & SA & SA \\
\hline 3 & $\begin{array}{l}\text { Jeśli dziewczyna idzie do pokoju sama z chłopakiem, } \\
\text { kiedy są na przyjęciu, to jest to jej wina, jeśli zostanie zgwałcona. }\end{array}$ & SA & SA & SA \\
\hline 4 & Jeśli dziewczyna zachowuje się jak zdzira, w końcu wpakuje się w kłopoty. & SA & SA & SA \\
\hline 5 & Kiedy faceci gwałcą, to zazwyczaj jest to spowodowane ich silną żądzą seksu. & $\mathrm{MT}^{* *}$ & MT & MT \\
\hline 6 & $\begin{array}{l}\text { Faceci zazwyczaj nie zamierzają zmuszać dziewczyny } \\
\text { do seksu, ale czasami nie mogą się pohamować seksualnie. }\end{array}$ & MT & MT & MT \\
\hline 7 & Gwałt ma miejsce, kiedy popęd seksualny mężczyzny wymyka się spod kontroli. & MT & MT & MT \\
\hline 8 & Kiedy facet jest pijany, może kogoś zgwałcić nieumyślnie. & MT & MT & $\mathrm{JD} * * *$ \\
\hline 9 & Jeśli dwie osoby są pijane - to nie może być gwałt. & MT & $\mathrm{NR} * * * *$ & $\mathrm{JD}$ \\
\hline 10 & $\begin{array}{l}\text { Nie powinno uznawać się za gwałt zbliżenia, do którego doszło kiedy } \\
\text { facet był pijany i nie zdawał sobie sprawy z tego, co robił. }\end{array}$ & MT & NR & $\mathrm{JD}$ \\
\hline 11 & $\begin{array}{l}\text { Jeśli dziewczyna nie stawia fizycznego oporu - nawet jeśli protestuje werbalnie } \\
\text { - to nie powinno się tego uznawać za gwałt. }\end{array}$ & NR & NR & NR \\
\hline 12 & Jeśli dziewczyna nie odpowiada na atak siłą fizyczną, nie można tak naprawdę mówić o gwałcie. & NR & NR & NR \\
\hline 13 & Często dziewczyny, które twierdza, że zostały zgwałcone, zgodziły się na seks, ale później tego żałowały. & $\mathrm{SL} * * * * *$ & SL & SL \\
\hline 14 & Oskarżenia o gwałt są często używane jako sposób na odegranie się na facetach. & SL & SL & SL \\
\hline 15 & $\begin{array}{l}\text { Dziewczyny, które twierdza, że zostały zgwałcone, często } \\
\text { prowokowały faceta, a potem miały wyrzuty sumienia. }\end{array}$ & SL & SL & SL \\
\hline 16 & Często dziewczyny, które twierdzą, że zostały zgwałcone, po prostu mają problemy emocjonalne. & SL & SL & SL \\
\hline 17 & Jeśli oskarżony" gwałciciel" nie ma broni, tak naprawdę nie można nazwać tego gwałtem. & NR & NR & NR \\
\hline 18 & Dziewczyny, które zostaną przyłapane na zdradzie, czasem twierdzą, że zostały zgwałcone. & SL & SL & SL \\
\hline 19 & Jeśli dziewczyna nie powie" nie", to nie może twierdzić, że została zgwałcona. & NR & NR & NR \\
\hline
\end{tabular}

*SA She Asked For It, **MT He Didn’t Mean To, ***JD He Was Just Drunk, **** NR It Wasn't Really Rape, *****SL She Lied

Open Access This article is licensed under a Creative Commons Attribution 4.0 International License, which permits use, sharing, adaptation, distribution and reproduction in any medium or format, as long as you give appropriate credit to the original author(s) and the source, provide a link to the Creative Commons licence, and indicate if changes were made. The images or other third party material in this article are included in the article's Creative Commons licence, unless indicated otherwise in a credit line to the material. If material is not included in the article's Creative Commons licence and your intended use is not permitted by statutory regulation or exceeds the permitted use, you will need to obtain permission directly from the copyright holder. To view a copy of this licence, visit http://creativecommons.org/licenses/by/4.0/.

\section{References}

Abbey, A., Jacques-Tiura, A. J., \& LeBreton, J. M. (2011). Risk factors for sexual aggression in young men: An expansion of the confluence model. Aggressive Behavior, 37(5), 450-464. https://doi.org/10. 1002/ab.20399.

Aosved, A. C., \& Long, P. J. (2006). Co-occurrence of RMA, sexism, racism, homophobia, ageism, classism, and religious intolerance. Sex Roles, 55(7-8), 481-492. https://doi.org/10.1007/s11199-0069101-4.
Arafat, S. M. Y., Chowdhury, H. R., Qusar, M. S., \& Hafez, M. (2016). Cross Cultural Adaptation \& Psychometric Validation of research instruments: A methodological review. Journal of Behavioral Health, 5(3), 129-136. https://doi.org/10.5455/jbh.20160615121755.

Areh, I., Mesko, G., \& Umek, P. (2009). Attribution of personal characteristics to victims of rape - police officers' perspectives. Studia Psychologica, 51(1), 85-100.

Awang, Z. (2012). Structural equation modeling using Amos graphic. Shah Alam: UiTM Press.

Barn, R., \& Powers, R. A. (2018). Rape myth acceptance in contemporary times: A comparative study of university students in India and the United Kingdom. Journal of Interpersonal Violence, 088626051877575. https://doi.org/10.1177/0886260518775750.

Barnett, M. D., \& Hilz, E. N. (2017). The psychology of the politics of rape: Political ideology, moral foundations, and attitudes toward rape. Violence Against Women, 24(5), 545-564. https://doi.org/10. 1177/1077801217708887.

Bendixen, M., \& Kennair, L. E. O. (2017). When less is more: Psychometric properties of Norwegian short-forms of the ambivalent sexism scales (ASI and AMI) and the Illinois rape myth acceptance (IRMA) scale. Scandinavian Journal of Psychology, 58(6), 541-550. https://doi.org/10.1111/sjop.12392. 
Broussard, K., \& Warner, R. (2018). Gender nonconformity is perceived differently for Cisgender and transgender targets. Sex Roles, 80(78), 409-428. https://doi.org/10.1007/s11199-018-0947-z.

Burt, M. R. (1980). Cultural myths and supports for rape. Journal of Personality and Social Psychology, 38(2), 217-230. https://doi. org/10.1037/0022-3514.38.

Chapleau, K. M., \& Oswald, D. L. (2010). Power, sex, and rape myth acceptance: Testing two models of rape proclivity. Journal of Sex Research, 47(1), 66-78. https://doi.org/10.1080/00224490902954323.

Chapleau, K. M., \& Oswald, D. L. (2013). Status, threat, and stereotypes: Understanding the function of RMA. Social Justice Research, 26(1), $18-41$.

Chapleau, K. M., \& Oswald, D. L. (2014). A system justification view of sexual violence: Legitimizing gender inequality and reduced moral outrage are connected to greater rape myth acceptance. Journal of Trauma \& Dissociation, 15(2), 204-218. https://doi.org/10.1080/ 15299732.2014.867573.

Chapleau, K. M., Oswald, D. L., \& Russell, B. L. (2007). How ambivalent sexism toward women and men support rape myth acceptance. Sex Roles, 57(1-2), 131-136. https://doi.org/10.1007/s11199-0079196-2.

Ching, B. H. H., \& Xu, J. T. (2018). The effects of gender neuroessentialism on transprejudice: An experimental study. Sex Roles, 78, 228-241. https://doi.org/10.1007/s11199-017-0786-3.

Chudasama, R. K., Kadri, A. M., Zalavadiya, D., Joshi, N., \& Bhola, C. (2013). Attitude and myths towards rape among medical students in Rajkot, India. Online Journal of Health and Allied Science, 12(3), $1-6$.

Cooper Stoll, L., Lilley, T. G., \& Pinter, K. (2017). Gender-blind sexism and rape myth acceptance. Violence Against Women, 23(1), 28-45. https://doi.org/10.1177/1077801216636239.

Criminal Law of Lagos State. (2011). Article 260. Retrieved from: http:// lagosministryofjustice.org/wp-content/themes/moj/documents/ CRIMINAL CONDUCT.pdf. Accessed 22 Jan 2021.

Crowne, D. P., \& Marlowe, D. (1960). A new scale of social desirability independent of psychopathology. Journal of Consulting Psychology, 24(4), 349-354. https://doi.org/10.1037/h0047358.

Dalbert, C., Lipkus, I. M., Sallay, H., \& Goch, I. (2001). A just and an unjust world: Structure and validity of different world beliefs. Personality and Individual Differences, 30, 561-577. https://doi. org/10.1016/S0191-8869(00)00055-6.

Debowska, A., Boduszek, D., Dhingra, K., Kola, S., \& Meller-Prunska, A. (2015). The role of psychopathy and exposure to violence in rape myth acceptance. Journal of Interpersonal Violence, 30(15), 27512770. https://doi.org/10.1177/0886260514553635.

Debowska, A., Boduszek, D., Dhingra, K., \& DeLisi, M. (2016). The effect of male incarceration on rape myth acceptance: Application of propensity score matching technique. Deviant Behavior, 37, 1-7. https://doi.org/10.1080/01639625.2015.1060805.

Drwal, R. Ł., \& Wilczyńska, J. T. (1980). Opracowanie Kwestionariusza Aprobaty Społecznej [construction of the social desirability questionnaire]. Przeglad Psychologiczny, 23(3), 569-583.

Egan, R., \& Wilson, J. C. (2012). Rape victims' attitudes to rape myth acceptance. Psychiatry, Psychology and Law, 19(3), 345-357. https://doi.org/10.1080/13218719.2011.585128.

Funke, F. (2005). The dimensionality of right-wing authoritarianism: Lesson from the dilemma between theory and measurement. Political Psychology, 26, 195-218. https://doi.org/10.1111/j.14679221.2005.00415.x.

Fus, T. (2006). Criminalizing marital rape: A comparison of judicial and legislative approaches. Vanderbilt Journal of Transnational Law, $39(2), 481-517$.

Gazeta Wrocławska. (2020). Rok w zawieszeniu za seks z 14-latka. Sad: Gwattu nie byto, bo nie krzyczała [A year in suspension for sex with a 14-year-old girl. Court: there was no rape because she was not screaming]. Retrieved from: https://gazetawroclawska.pl/rok-w- zawieszeniu-za-seks-z-14latka-sad-gwaltu-nie-bylo-bo-niekrzyczala/ar/c1-15178474. Accessed 22 Jan 2021.

Giovannelli, T. S., \& Jackson, L. (2013). Sexual violence perceptions among Christian college students. Mental Health, Religion and Culture, 16(3), 254-272. https://doi.org/10.1080/13674676.2012.657618.

Glick, P., \& Fiske, S. T. (1996). The ambivalent sexism inventory: Differentiating hostile and benevolent sexism. Journal of Personality and Social Psychology, 70, 491-512. https://doi.org/ 10.1037/0022-3514.70.3.491.

Goldenberg, L., \& Forgas, J. P. (2012). Can happy mood reduce the just world bias? Affective influences on blaming the victim. Journal of Experimental Social Psychology, 48(1), 239-243. https://doi.org/ 10.1016/j.jesp.2011.07.007.

Grabowska, M., \& Rawłuszko, M. (2016). Universality and prevalence of sexual violence against women: Results of quantitative research. In M. Grabowska \& A. Grzybek (Eds.), Breaking the taboo. Report on sexual violence (pp. 11-23). Foundation for Equality and Emancipation STER: Warsaw Retrieved from: http://www. fundacjaster.org.pl/upload/R_ENG-final.pdf. Accessed 22 Jan 2021.

Grzesiak-Feldman, M. (2012). Prawicowy autorytaryzm oraz orientacja na dominację społeczną jako predyktory różnych form myślenia spiskowego [right-wing authoritarianism and social dominance orientation as predictors of various forms of conspiracy thinking]. Psychologia Społeczna [Social Psychology Bulletin], 7, 1(20), 4863.

Guàrdia-Olmos, J., Peró-Cebollero, M., Benítez-Borrego, S., \& Fox, J. (2013). Using SEM Library in R software to Analyze Exploratory Structural Equation Models. Paper presented at 59th ISI world statistics congress, Hong-Kong. Retrieved from: https://www.statistics. gov.hk/wsc/CPS105-P6-S.pdf. Accessed 22 Jan 2021.

Guay, F., Morin, A. J. S., Litalien, D., Valois, P., \& Vallerand, R. J. (2015). Application of exploratory structural equation modeling to evaluate the academic motivation scale. The Journal of Experimental Education, 83(1), 51-82. https://doi.org/10.1080/ 00220973.2013 .876231

Hantzi, A., Lampridis, E., Tsantila, K., \& Bohner, G. (2015). Validation of the Greek acceptance of modern myths about sexual aggression (AMMSA) scale: Examining its relationships with sexist and conservative political beliefs. International Journal of Conflict and Violence, 9(1), 122-133. https://doi.org/10.4119/UNIBI/ijcv.498.

Heath, N. M., Lynch, S. M., Fritch, A. M., \& Wong, M. M. (2013). RMA impacts the reporting of rape to the police: A study of incarcerated women. Violence Against Women, 19(9), 1065-1078. https://doi. org/10.1177/1077801213501841.

Heaven, P. C. L., Connors, J., \& Pretorius, A. (1998). Victim characteristics and attribution of rape blame in Australia and South Africa. Journal of Social Psychology, 138(1), 131-133.

Helgeson, V. J. (2005). Psychology of gender (2nd ed.). Upper Saddle River: Pearson Education.

Herman, D. F. (1984). Rape culture. In J. Freeman (Ed.), Women: A feminist perspective. Mayfield: Mountain View.

Herweyer, J. A. (2015). Rape perception based on religious orientation, gender and length of relationship (master dissertation). Retrieved from: http://commons.nmu.edu/cgi/viewcontent.cgi?article= 1074\&context=theses. Accessed 22 Jan 2021.

Hine, B., \& Murphy, A. (2017). The impact of victim-perpetrator relationship, reputation and initial point of resistance on officers' responsibility and authenticity ratings towards hypothetical rape cases. Journal of Criminal Justice, 49, 1-13. https://doi.org/10.1016/j. jcrimjus.2017.01.001.

Hine, B., \& Murphy, A. (2018). The influence of 'high' vs. 'low' rape myth acceptance on police officers' judgements of victim and perpetrator responsibility, and rape authenticity. Journal of Criminal Justice, 60, 100-107. https://doi.org/10.1016/j.jcrimjus.2018.08. 001 . 
Hu, L., \& Bentler, P. (1999). Cutoff criteria for fit indices in covariance structure analysis: Conventional criteria versus new alternatives. Structural Equation Modeling, 6, 1-55. https://doi.org/10.1080/ 10705519909540118.

Hudson, S. M., Wales, D. S., Bakker, L., \& Ward, T. (2002). Dynamic risk factors: The Kia Marama evaluation. Sexual Abuse: A Journal of Research and Treatment, 14, 103-119. https://doi.org/10.1177/ 107906320201400203.

Iacobucci, D. (Ed.). (2001). Journal of consumer Psychology's special issue on methodological and statistical concerns of the experimental behavioral Researcher, 10 (1\&2). Mahwah: Lawrence Erlbaum Associates.

Iconis, R. (2008). RMA in college students: A literature review. Contemporary Issues In Education Research, 1(2), 47-52.

Izdebski, Z. (2012). Seksualność Polaków na poczatku XX wieku. Studium badawcze [sexuality of poles at the beginning of XXIst century. A research study]. Kraków: Wydawnictwo Uniwersytetu Jagiellońskiego.

Jewkes, R., Sikweyiya, Y., Morrell, R., \& Dunkle, K. (2011). Gender inequitable masculinity and sexual entitlement in rape perpetration South Africa: Findings of struck a cross-sectional study. PLoS One, 6(12), e29590. https://doi.org/10.1371/journal.pone.0029590.

Jost, J. T., \& Banaji, M. R. (1994). The role of stereotyping in system justification and the production of false consciousness. British Journal of Social Psychology, 33, 1-27. https://doi.org/10.1111/j. 2044-8309.1994.tb01008.x.

Kay, A. C., \& Jost, J. T. (2003). Complementary justice: Effects of "poor but happy" and "poor but honest" stereotype exemplars on system justification and implicit activation of the justice motive. Journal of Personality and Social Psychology, 85(5), 823-837. https://doi.org/ 10.1037/0022-3514.85.5.823.

Klebaniuk, J. (2010). Orientacja na dominację społeczną i usprawiedliwianie systemu w kontekście nierówności międzypaństwowych [social dominance orientation and system justification in the context of between-state inequalities]. Psychologia Społeczna [Social Psychology Bulletin], 5, 1(13), 42-56.

Koss, M. P., \& Dinero, T. E. (1988). Predictors of sexual aggression among a national sample of male college students. Annals of the New York Academy of Sciences, 528, 133-147. https://doi.org/10. 1111/j.1749-6632.1988.tb50856.x.

Krug, E. G., Dahlberg, L. L., Mercy, J. A., Zwi, A. B., \& Lozano, R. (2002). World report on violence and health. Geneva: World Health Organization.

Lee, J., Pomeroy, E. C., Yoo, S.-K., \& Rheinboldt, K. T. (2005). Attitudes toward rape- a comparison between Asian and Caucasian college students. Violence Against Women, 11(2), 177-196. https:// doi.org/10.1177/1077801204271663.

Lench, H. C., \& Chang, E. S. (2007). Belief in an unjust world: When beliefs in a just world fail. Journal of Personality Assessment, 89(2), 126-135. https://doi.org/10.1080/00223890701468477.

Łyś, A., Bargiel-Matusiewicz, K., Studzińska, A., Folkierska-Żukowska, M. (2021). Parametry psychometryczne polskiej wersji Inwentarza Ambiwalencji wobec Mężczyzn na przykładzie badania seksizmu wobec mężczyzn wśród polskich studentów [Psychometric properties of the Polish version of the Ambivalence towards Men Inventory on the example of a study of sexism toward men among Polish students]. In: Obrycka, M., Piekarski, G., Sałapata, M. A. (red.), Edukacja równościowa: tworzenie przestrzeni i warunków dla innego [Equality education: creating the space and condition for the different]. Warszawa: Oficyna Wydawnicza Impuls.

Maercker, A., \& Müller, J. (2004). Social acknowledgment as a victim or survivor: A scale to measure a recovery factor of PTSD. Journal of Traumatic Stress, 17, 345-351. https://doi.org/10.1023/B:JOTS. $0000038484.15488 .3 \mathrm{~d}$

Maercker, A., Povilonyte, M., Lianova, R., \& Pöhlmann, K. (2009). Is acknowledgment of trauma a protective factor? European
Psychologist, 14, 249-254. https://doi.org/10.1027/1016-9040.14. 3.249 .

Malamuth, N. M., Linz, D., Heavey, C. L., Barnes, G., \& Acker, M. (1995). Using the confluence model of sexual aggression to predict men's conflict with women: A 10-year follow-up study. Journal of Personality and Social Psychology, 69(2), 353-369. https://doi.org/ 10.1037/0022-3514.69.2.353.

McMahon, J. J. (2005). Marital rape laws 1976-2002: from exemptions to prohibitions (master's thesis, University of Georgia). Retrieved from: https://pdfs.semanticscholar.org/db09/ ae24ef088bb84a29b5043e00ddd384d8c389.pdf. Accessed 22 Jan 2021.

McMahon, S., \& Farmer, G. L. (2011). An updated measure for assessing subtle rape myths. Social Work Research, 35(2), 71-81. https://doi. org/10.1093/swr/35.2.71.

Melanson, P. K. (1998). Belief in male rape myths: A test of two competing theories (doctoral dissertation, Queen's University). Dissertation Abstracts International, 59, 5620.

Mikołajczak, M., \& Pietrzak, J. (2014). Ambivalent sexism and religion: Connected through values. Sex Roles, 70(9-10), 387-399. https:// doi.org/10.1007/s11199-014-0379-3.

Moyano, M., Monge, F. S., \& Sierra, J. C. (2017). Predictors of sexual aggression in adolescents: Gender dominance vs. rape supportive attitudes. The European Journal of Psychology Applied to Legal Context, 9, 25-31. https://doi.org/10.1016/j.ejpal.2016.06.001.

Müller, J., Moergeli, H., \& Maercker, A. (2008). Disclosure and social acknowledgement as predictors of recovery from posttraumatic stress: A longitudinal study in crime victims. Canadian Journal of Psychiatry, 53, 160-168. https://doi.org/10.1177/070674370805300306.

Nunnally, J. C., \& Bernstein, I. H. (1994). Psychometric theory (3rd ed.). New York: McGraw-Hill.

Orchowski, L. M., Untied, A. S., \& Gidycz, C. A. (2013). Social reactions to disclosure of sexual victimization and adjustment among survivors of sexual assault. Journal of Interpersonal Violence, 28(10), 2005-2023. https://doi.org/10.1177/0886260512471085.

Pacilli, M. G., Pagliaro, S., Taurino, A., Spaccatini, F., Giovannelli, I., Massaro, G., \& Caporale, F. (2017). Impact of gender essentialism on heterosexuals' negative attitudes toward same-sex parenting. Psicologia Sociale, 12(3), 317-334. https://doi.org/10.1482/87888.

Page, A. D. (2008). Judging women and defining crime: Police officers' attitudes toward women and rape. Sociological Spectrum, 28, 389 411. https://doi.org/10.1080/02732170802053621.

Page, A. D. (2010). True colors: Police officers and rape myth acceptance. Feminist Criminology, 5(4), 315-334. https://doi.org/10. $1177 / 1557085110384108$

Papp, L. J., \& Erchull, M. J. (2017). Objectification and system justification impact rape avoidance behaviors. Sex Roles, 76, 110-120. https://doi.org/10.1007/s11199-016-0660-8.

Payne, D. L., Lonsway, K. A., \& Fitzgerald, L. F. (1999). Rape myth acceptance: Exploration of its structure and its measurement using the Illinois rape myth acceptance scale. Journal of Research in Personality, 33, 27-68.

Penal Code [UK]. (2008). Article 117. Retrieved from: http://agc.gov.ms/ wp-content/uploads/2010/02/penal code.pdf

Penal Code Act [Nigeria]. (1960). Art. 282. Retrieved from: http:// oceansbeyondpiracy.org/sites/default/files/Nigeria_Penal_Code Act 1960.pdf. Accessed 22 Jan 2021.

Radkiewicz, P. (2011). Ile jest autorytaryzmu w prawicowym autorytaryzmie? Krytyka użyteczności narzędzia pomiaru [how much of the authoritarianism is in the right-wing authoritarianism? A critics of usefulness of the measurement tool]. Psychologia Społeczna, 6, 2(17), 97-112.

Rebeiz, M. J., \& Harb, C. (2010). Perceptions of rape and attitudes toward women in a sample of Lebanese students. Journal of Interpersonal Violence, 25(4), 735-752. https://doi.org/10.1177/ 0886260509334410 . 
Relyea, M., \& Ullman, S. E. (2015). Unsupported or turned against: Understanding how two types of negative social reactions to sexual assault relate to post-assault outcomes. Psychology of Women Quarterly, 39, 37-52. https://doi.org/10.1177/0361684313512610.

Rosseel, Y. (2020). The Lavaan tutorial. Department of Data Analysis: Ghent University. Retrieved: https://lavaan.ugent.be/tutorial/ tutorial.pdf. Accessed 22 Jan 2021.

Russell, K. J., \& Hand, C. J. (2017). Rape myth acceptance, victim blame attribution and just world beliefs: A rapid evidence assessment. Aggression and Violent Behavior, 37, 153-160. https://doi.org/10. 1016/j.avb.2017.10.008.

Sakallı-Uğurlu, N., Yalçın, Z. S., \& Glick, P. (2007). Ambivalent sexism, belief in a just world, and empathy as predictors of Turkish students' attitudes toward rape victims. Sex Roles, 57, 889-895. https://doi. org/10.1007/s11199-007-9313-2.

Sarmiento, I. (2011). Rape stereotypes and labeling: Awareness of victimization and trauma. Psychological Reports, 108(1), 141-148. https://doi.org/10.2466/07.13.16.PR0.108.1.141-148.

Saunders, A. (2012, January). Speech on the prosecution of rape and serious sexual offences. Speech from 30.01.2012, Retrieved from: $\mathrm{http}: / / w w w . c p s . g o v . u k / n e w s / a r t i c l e s / s p e e c h \_o n \_t h e$ prosecution of_rape_and_serious_sexual_offences_by_alison_saunders_chief crown prosecutor for london/

Schneider, L. J., Mori, L. T., Lambert, P. L., \& Wong, A. O. (2009). The role of gender and ethnicity in perceptions of rape and its aftereffects. Sex Roles, 60, 410-421. https://doi.org/10.1007/s11199-008-9545-9.

Sidanius, J., \& Pratto, F. (1999). Social dominance: An intergroup theory of social hierarchy and oppression. New York: Cambridge University Press.

Skewes, L., Fine, C., \& Haslam, N. (2018). Beyond Mars and Venus: The role of gender essentialism in support for gender inequality and backlash. PLoS One, 13(7), e0200921. https://doi.org/10.1371/ journal.pone.0200921.

Skrzypińska, K. (2003). Dlaczego młodzi Polacy nie wierza w świat sprawiedliwy, ale wierzą w człowieka? [why young poles do not believe in a just world but they do believe in a human?] in: B. Wojciszke, M. Plopa (Ed.), Osobowość a procesy psychiczne $i$ zachowanie (pp. 261-287). Kraków: Oficyna Wydawnicza Impuls.

Skrzypińska, K. (2008). Osobowość a wiara w człowieka i w sprawiedliwy świat w kontekście jakości życia [personality and believe in human nature and just world in a context of a quality of life]. In: M. Plopa, M. Błażek (Ed.), Współczesny człowiek w świetle dylematów i wyzwań: Perspektywa psychologiczna (pp. 77-83). Kraków: Oficyna Wydawnicza Impuls.

Smith, S. G., Chen, J., Basile, K. C., Gilbert, L. K., Merrick, M. T., Patel, N., Walling, M., \& Jain, A. (2017). The National Intimate Partner and sexual violence survey (NISVS): 2010-2012 state report. Atlanta, GA: National Center for Injury Prevention and Control, Centers for Disease Control and Prevention.

Stephens, T., Kamimura, A., Yamawaki, N., Bhattacharya, H., Mo, W., Birkholz, R., Makomenaw, A., \& Olson, L. M. (2016). Rape myth acceptance among college students in the United States, Japan, and India. SAGE Open, 6(4), 215824401667501. https://doi.org/10. $1177 / 2158244016675015$.

Strömwall, L. A., Alfredsson, H., \& Landström, S. (2013). Blame attributions and rape: Effects of belief in a just world and relationship level. Legal and Criminological Psychology, 18, 254-261. https:// doi.org/10.1111/j.2044-8333.2012.02044.x.

Struckman-Johnson, C., \& Struckman-Johnson, D. (1992). Acceptance of male rape myths among college men and women. Sex Roles, 27(3/4), 85-100. https://doi.org/10.1007/BF00290011.

Studzińska, A., Wojciszke, B. (2014). Przekonania o genezie różnic płci a legitymizacja nierówności kobiet i mężczyzn [beliefs on origins of the gender differences and legitimizing of the inequalities between men and women]. Psychologia Spoleczna [Social Psychology Bulletin], 9, 4(31), 396-408.
Suarez, E., \& Gadalla, T. M. (2010). Stop blaming the victim: A metaanalysis on rape myths. Journal of Interpersonal Violence, 25(11), 2010-2035.

Süssenbach, P., Albrecht, S., \& Bohner, G. (2017). Implicit judgments of rape cases: An experiment on the determinants and consequences of implicit evaluations in a rape case. Psychology, Crime \& Law, 23, 291-304. https://doi.org/10.1080/1068316X.2016.1247160.

Swigger, N., Meyer, M., (2018). Gender essentialism and responses to candidates' messages. Political Psychology, $0(0), 1-20$. https://doi. org/10.1111/pops. 12556.

Swiss Criminal Code. (1937/2018). Article 190. Retrieved from: https:// www.admin.ch/opc/en/classified-compilation/19370083/ 201801010000/311.0.pdf

TVN24. (2014). Korwin-Mikke o gwattach: Kobiety udaja, że stawiaja opór $i$ to jest normalne [Korwin-Mikke about rapes: Women pretend resistance and this is normal]. Retrieved from: https://tvn24.pl/ programy/korwin-mikke-o-gwaltach-kobiety-udaja-ze-stawiajaopor-i-to-jest-normalne-ra430055-3361348

Ullman, S. E., Filipas, H. H., Townsend, S. M., \& Starzynski, L. L. (2006). The role of victim-offender relationship in Women's sexual assault experiences. Journal of Interpersonal Violence, 21(6), 798 819. https://doi.org/10.1177/0886260506288590.

van der Bruggen, M., \& Grubb, A. R. (2014). A review of the literature relating to rape victim blaming: An analysis of the impact of observer and victim characteristics on attribution of blame in rape cases. Aggression and Violent Behavior, 19(5), 523-531. https://doi.org/ 10.1016/j.avb.2014.07.008.

Vance, K., Sutter, M., Perrin, P. B., \& Heesacker, M. (2015). The Media's sexual objectification of women, rape myth acceptance, and interpersonal violence. Journal of Aggression, Maltreatment \& Trauma, 24, 569-587. https://doi.org/10.1080/10926771.2015. 1029179 .

Vilagut, G. (2014). Test-retest reliability. In A. C. Michalos (Ed.), Encyclopedia of quality of life and well-being research (pp. 66226625). Dordrecht: Springer Science+Business Media.

Vonderhaar, R. L., \& Carmody, D. C. (2014). There are no "innocent victims": The influence of just world beliefs and prior victimization on rape myth acceptance. Journal of Interpersonal Violence, 30(10), 1-18. https://doi.org/10.1177/0886260514549196.

Walfield, S. (2018). "Men cannot be raped": Correlates of male rape myth acceptance. Journal of Interpersonal Violence, $O(00), 1-27 . \mathrm{https}: / /$ doi.org/10.1177/0886260518817777.

Ward, C. (1995). Attitudes toward rape. Feminist and socialpsychological perspectives. London: Sage.

Waterhouse, G. F., Reynolds, A., \& Egan, V. (2016). Myths and legends: The reality of rape offences reported to a UK police force. The European Journal of Psychology Applied to Legal Context, 8, 110. https://doi.org/10.1016/j.ejpal.2015.04.001.

Widman, L., \& Olson, M. (2013). On the relationship between automatic attitudes and self-reported sexual assault in men. Archives of Sexual Behavior, 42, 813-823. https://doi.org/10.1007/s10508-012-9970-2.

Wilton, L. S., Bell, A. N., Carpinella, C. M., Young, D. M., Meyers, C., \& Clapham, R. (2018). Lay theories of gender influence, Support for Women and Transgender People's Legal Rights. Social Psychological and Personality Science, 1-12. https://doi.org/10. 1177/1948550618803608.

Yamawaki, N., \& Tschanz, B. T. (2005). Rape perception differences between Japanese and American college students: On the mediating influence of gender role Traditionality. Sex Roles, 52(5/6), 379-392. https://doi.org/10.1007/s11199-005-2680-7.

Publisher's Note Springer Nature remains neutral with regard to jurisdictional claims in published maps and institutional affiliations. 